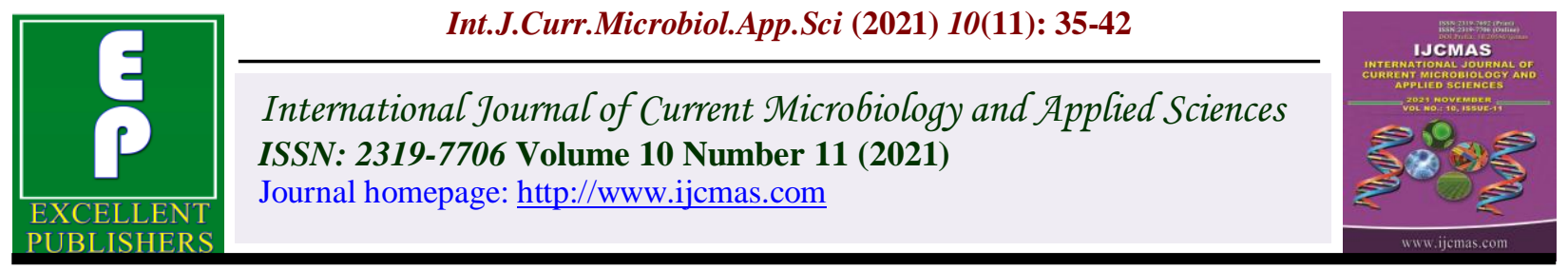

\title{
Response of Late Sown Pigeonpea (Cajanus cajan (L.) Mill Sp.) to Nutrient and Pest Management
}

\author{
Akhilesh Mishra* and Geeta Rai \\ Legume Section, C.S.A. University of agriculture and Technology, Kanpur, \\ Uttar Pradesh, India \\ *Corresponding author
}

\section{Keywords}

Growth attributes,

Yield attributes,

Micronutrients,

Nutrient

management, Pest

management

Article Info

Received:

10 October 2021

Accepted:

30 October 2021

Available Online:

10 November 2021

\section{A B S T R A C T}

A field experiment was conducted at Oilseed Research Farm, C.S.A. University of agriculture and Technology, Kanpur (Uttar Pradesh) continuously three years since 2016-17 to 2018-19 to study the response of late sown pigeonpea (Cajanus cajan L. Millsp.) to nutrient and pest management. The experiment was laid out in a Randomized Complete Block Design in three replications. Among the all treatments, recommended dose of fertilizer (N:P:K:S:Zn kg ha $\left.{ }^{-1}:: 20: 50: 20: 20: 20\right)$ application was common. Investigation results revealed that the application of T6 $(\mathrm{RDF}+2 \%$ urea $+0.5 \% \mathrm{~B}+0.5 \% \mathrm{Zn}$ spray at $50 \%$ flowering $)+$ Indoxacarb at flowering + one systemic insecticide 15 days after first spray was produces $30.89 \%$ higher grain yield and Gross income; and $28.27 \%$ higher B:C cost ratio over the application of RDF. Therefore, in comparison to RDF, particularly on economic point of view, we may conclude that the application of RDF $+2 \%$ urea $+0.5 \% \mathrm{~B}+0.5 \% \mathrm{Zn}$ spray at $50 \%$ flowering + Indoxacarb $14.5 \% \mathrm{SC}$ at flowering + one systemic insecticide 15 days after first spray may be suggested for nutrient and pest management practice in long duration pigeonpea to attained the maximum grain yield and economic return.

\section{Introduction}

Pigeonpea (Cajanus cajan (L.) Millsp.) is one of the important Kharif season pulse crop, it is commonly known as Red gram, Arhar or Tur. Among all the pulses, it is the 2nd most important crop after the gram among all the pulses in the country. India ranks $1^{\text {st }}$ in area and production in the world, with $80 \%$ and
$67 \%$ of world's acreage and production respectively. It is the most versatile food legume with diversified uses as food, feed, fodder and fuel. It accounts for 5\% of global acreage and production, Asia is nearly the sole contributor and of that too, India alone accounts for over three-fourths of area and four-fifths of production (Ahlawat et al., 2005). 
Pigeonpea is predominantly a crop of tropical areas mainly cultivated in semi-arid regions of India. It can be successfully grown with a temperature range from $26^{\circ} \mathrm{C}$ to $30^{\circ} \mathrm{C}$ in the rainy season (June to October) at the vegetative growth stage and $17^{\circ} \mathrm{C}$ to $22^{\circ} \mathrm{C}$ in the post rainy (November to March) season during flowering, fruiting and maturity stage. This crop is very sensitive to low radiation at pod development stage, therefore during flowering and podding stage cloudy weather, fog and low temperature, leads to poor pod formation and resulted low yield. It is suitable for rainfed situation with an area of $4.4 \mathrm{~m}$ ha, production $4.2 \mathrm{mt}$ and productivity $954 \mathrm{~kg} / \mathrm{ha}$ in the country (Anonymous, 2017-18). However, Area of pigeonpea in Uttar Pradesh in 2018-19 was 2.51 lakh ha and production 2.72 lakh tonnes with average productivity 1084 kg/ha (Kharif Pulses Prospects, 2020-21 DPD, Bhopal pp.2).

Among the pulses, the pigeonpea is an important dietary component of human beings, especially to the people which are vegetarians. Being a pulse, it also plays an important role in improving the soil fertility and consequently it improves the productivity of succeeding crops (Kumar Rao, 1990). Pigeon pea is the rich sources of dietary protein, carbohydrate and certain minerals in the vegetarian diet in India (Gopalan et al., 1971). Besides being the major sources of dietary protein, they also plays an important role in sustaining nutrient level in soil productivity by fixing atmospheric nitrogen (Kumar Rao and Dart, 1987) for crop productivity. To meet out the demands of pulses of ever-increasing population of our country, it is very necessary to increase the production and productivity of pulse crops. In order to increase the production, there is need to increase productivity by using available resources most efficiently. Application of balanced fertilizers and nutrient continued to play a key role in augmenting higher crop production but reckless use of it deteriorates the soil health, energy conserving ecosystem and economics. Eventually, an adequate use and fertilizer management is appreciable to achieve the higher yield and it is needed to be worked out within a particular manner and timeframe.

Low and imbalanced use of fertilizers is one of the major reasons for low productivity. It has been recognized that $\mathrm{N}, \mathrm{P}$ and $\mathrm{K}$ fertilizers alone are not always sufficient to provide balanced nutrition for optimal yield and quality of pigeonpea (Jain et al., 2007). Pigeonpea flowers profusely during in the month of November-December, a higher per cent of flower drop (70-96\%) without setting into the pods was observed. Grain yield considerably depends upon percentage of flowers transformed into the pods. Mineral nutrients are known to develop the economic source-sink relationship into the plants, that ultimately increase the flowering, fruit setting and seed formation, thereby resulted as increase in grain yield. Pre-mature dropping of flowers and fruits lead to reduced realization of source-sink potential. Thus, flower and fruit dropping are considered as a bottleneck in grain production. Plant nutrition is the key input to increase the production as well as productivity. Appropriate application of fertilizer is an important option that should be adopted in order to improve the crop yield. Considering low yield, agronomical practices of pigeonpea are required to be restandardized for realizing crop yield and potential. Among the different agronomic practices, foliar spray of micronutrients is most important factor in determining the yield.

Flowers retention in crop plant helps to opt the maximum yield. Another major constraint of realization of yield potential of pigeonpea includes, biotic and abiotic stresses which prevalent across all the pulses growing areas. Biotic stresses include the Insects and diseases i.e., phytophthora blight, sterility mosaic, pod 
fly and pod borer are damage causing substantial losses. Among abiotic stresses, terminal drought, moisture stress and sudden rise and drop in temperature coupled with frost and foggy weather during the flower and pod initiation and pod development stage, inflicts major yield losses in production. Keeping all the views in mind an experiment was conducted to find out the response of late sown pigeonpea (Cajanus cajan L. Millsp.) to nutrient and pest management.

\section{Materials and Methods}

A field experiment was conducted continuously three years during kharif 201617 to 2018-19 at Oilseed Research Farm, Kalyanpur, Kanpur Uttar Pradesh (260 44'N; 80033 'E, $126 \mathrm{~m}$ of above mean sea level).

The soil of experimental field was well drained and levelled, experimental plots were sandy loam, low in organic carbon $(0.45 \%)$, $196 \mathrm{~kg}$ ha-1 available $\mathrm{N}$, medium in available P2O5 (25.20 kg ha-1), and available K2O (175 kg ha-1). The soil was moderately alkaline in reaction (pH 7.8). This was observed not favourable to make the nutrient availability, because $\mathrm{pH}$ range 6-7 seems to favour the availability of nutrients to the plants (Brady 1988). The experiment was laid out in Factorial randomized block design with eight treatments in three replications and variety was Amar. The treatments were consisting; (T1) RDF (20:50:20:20:20 kg NPKSZn kg/ha), (T2) RDF + 2\% urea spray at $50 \%$ flowering, (T3) RDF $+0.5 \%$ B spray at $50 \%$ flowering, (T4) RDF $+0.5 \% \mathrm{Zn}$ spray at $50 \%$ flowering, (T5) RDF $+2 \%$ urea $+0.5 \%$ $\mathrm{B}+0.5 \% \mathrm{Zn}$ spray at $50 \%$ flowering, (T6) RDF + Multi-micronutrient spray @ 2ml/lts of water, (T7) RDF + Indoxacarb at flowering $(@ 0.55 \mathrm{ml} / \mathrm{lt}$ of water $)+$ one systemic insecticide 15 days after first spray and (T8) T6 + Indoxacarb at flowering + one systemic insecticide 15 days after first spray.
Two irrigations were applied to the crop, $1^{\text {st }}$ at flowering and $2^{\text {nd }}$ at pod formation stage. Preemergence application of pendimethalin 30 EC @ 3.3 lt/ha was applied one day after sowing. A knapsack sprayer was used to spray the herbicides using a spray volume of 600 lts/ha. Two hand weeding operations were done at 20 and 45 DAS with the help of Khurpi in all the treatments. Sowing was done on ridges manually on hills with the help of Khurpi, rows and plant spacing at $60 \times 25 \mathrm{~cm}$ was maintained with average depth of $5 \mathrm{~cm}$ and seed rate was $18 \mathrm{~kg} / \mathrm{ha}$. All the plant protection measures were adopted as per treatments. At maturity stage, after leaving one row on each side as well as $50 \mathrm{~cm}$ along the width of each side, a net plot area of $5.0 \mathrm{~m}$ $\mathrm{x} 4.0 \mathrm{~m}(4 \mathrm{~m}$ long 6 rows at $75 \mathrm{~cm})$ was harvested separately, when two third to three fourth pods at maturity judged by changing their colour to brown. Data about the growth, yield attributes and yields were recorded.

The plants are usually cut with the help of sickle within $25 \mathrm{~cm}$ above the ground. Harvested plants should be left in the field for sun drying for 3-6 days depending on climatic conditions. Threshing is done by beating the pods with stick, seeds were cleaned by winnower and clean seeds should be sun dried for 3-4 days to bring their moisture content at $9-10 \%$ and yield was recorded. All the observations were statistically analyzed for their test of significance using the F-test (Gomez and Gomez, 1984). The significant of difference between treatment means were compared with $\mathrm{t}$ critical difference at $5 \%$ level of probability.

\section{Results and Discussion}

\section{Effect of nutrient and pest management on growth attributes}

Result revealed (Table-1) that plant height was influenced by different treatments, highest 
plant height $(214.66 \mathrm{~cm})$ was recorded with the application of $\mathrm{RDF}+$ Indoxacarb at flowering + one systemic insecticide 15 days after first spray followed by RDF and RDF + $2 \%$ Urea spray at 50\% flowering; and highest number of branches plant ${ }^{-1}$ (10.11) was recorded with T6 + Indoxacarb at flowering + one systemic insecticide 15 days after first spray, closely followed by RDF $+2 \%$ urea + $0.5 \% \mathrm{~B}+0.5 \% \mathrm{Zn}$ spray at $50 \%$ flowering (9.77) and RDF + Multi-micronutrient spray (a $2 \mathrm{ml} / \mathrm{lts}$ of water $(9.67)$ which was found higher by $15.14 \%$ and $11.27 \%$ over RDF application (8.78).

These finding are well supported by Kaur G. et al., (2015), Muthul (2016), and Kumar and Sharma (2020). The applications of $2 \%$ urea recorded maximum plant height and number of branches plant ${ }^{-1}$. This might be due to more availability of nitrogen, which plays a vital role in cell division.

Foliar application of nutrients increased plant height it might be readily due to absorption of nutrients through foliar application. Increased plant height is due to internodes elongation and vigorous root system. Multi-micronutrient spray also improves the root, flower growth and development thus improve overall health of the crop. As number of pods per plants is considered to be the major determinants in pulses, foliar feeding of micronutrient through multi micronutrient was able to enhanced number of seed per pod. It was also reported by Barrik and Rout (1990) and Elumle et al., (2019) where foliar application of nutrients at flowering and pod development stage might have been easily absorbed and better translocated in the plant and maintained constant requirement of nutrients at the reproductive stage of the crop.

\section{Effect of nutrient and pest management on yield attributes, yield and economics}

Result showed that highest number of pods plant $^{-1}$ was recorded with the application of $\mathrm{RDF}+$ Multi-micronutrient spray @ 2ml/lts of water (214.78), closely followed by T6 + Indoxacarb at flowering + one systemic insecticide 15 days after first spray (213.33), which was $4.29 \%$ and $2.60 \%$ more than application of RDF (204.55) respectively, and the grain pod $^{-1}$ was recorded highest with T6 + Indoxacarb at flowering + one systemic insecticide 15 days after first spray (4.55) closely followed byRDF $+0.5 \% \mathrm{~B}$ spray at $50 \%$ flowering (4.22), which were $23 \%$ and $14.98 \%$ more than the application of RDF (3.67), the number of pods plant ${ }^{-1}$ and grains pod $^{-1}$ increased by the application of micronutrients i.e. $\mathrm{Zn}$ and B. Similar findings were also reported by Gowda et al., (2015), Thamke (2017) and Archana Verma (2020). Grain yield, gross income and $\mathrm{B}: \mathrm{C}$ ratio of pigeon pea (Table 2) were significantly affected by nutrient and pest management (Figure 1 and Figure 2). Highest significant grain yield was recorded with the experimental treatment $\mathrm{T} 6$ + Indoxacarb at flowering + one systemic insecticide 15 days after first spray $\left(2779.45 \mathrm{~kg} \mathrm{ha}^{-1}\right)$; closely followed by RDF + Indoxacarb at flowering + one systemic insecticide 15 days after first spray (2633.65 kg ha ${ }^{-1}$ ) and RDF + Multimicronutrient spray @ $2 \mathrm{ml} / \mathrm{lts}$ of water $\left(2612.34 \mathrm{~kg} \mathrm{ha}^{-1}\right)$, which were $30.89 \%$, $24.02 \%$ and $23.02 \%$ higher than RDF (2123.44 kg ha-1). 
Table.1 Effect of nutrients and pest management on growth attributes of pigeonpea

\begin{tabular}{|c|c|c|c|c|}
\hline & & Treatments & $\begin{array}{l}\text { Plant } \\
\text { height } \\
(\mathrm{cm})\end{array}$ & $\begin{array}{l}\text { Branch } \\
\text { plant }^{-1}\end{array}$ \\
\hline 1. & $\left(\mathbf{T}_{1}\right)$ & RDF & 211.89 & 8.78 \\
\hline 2. & $\left(\mathbf{T}_{2}\right)$ & $\mathrm{RDF}+2 \%$ urea spray at $50 \%$ flowering & 210.33 & 9.22 \\
\hline 3. & $\left(\mathbf{T}_{3}\right)$ & $\mathrm{RDF}+0.5 \%$ B spray at $50 \%$ flowering & 208.66 & 8.89 \\
\hline 4. & $\left(\mathbf{T}_{4}\right)$ & $\mathrm{RDF}+0.5 \% \mathrm{Zn}$ spray at $50 \%$ flowering & 205.67 & 9.22 \\
\hline 5. & $\left(\mathbf{T}_{5}\right)$ & $\begin{array}{l}\mathrm{RDF}+2 \% \text { urea }+0.5 \% \mathrm{~B}+0.5 \% \mathrm{Zn} \text { spray at } 50 \% \\
\text { flowering }\end{array}$ & 208.33 & 9.77 \\
\hline 6. & $\left(\mathbf{T}_{6}\right)$ & RDF +Multi-micronutrient spray @ 2ml/lts of water & 208.33 & 9.67 \\
\hline & $\left(\mathbf{T}_{7}\right)$ & $\begin{array}{l}\text { RDF +Indoxacarb at flowering }+ \text { one systemic insecticide } \\
15 \text { days after first spray }\end{array}$ & 214.66 & 9.22 \\
\hline & $\left(\mathbf{T}_{8}\right)$ & $\begin{array}{l}\text { RDF + Indoxacarb at flowering + one systemic insecticide } \\
15 \text { days after first spray }\end{array}$ & 203.89 & 10.11 \\
\hline & & & 3.643 & 0.385 \\
\hline & $0.05)$ & & N/A & N/A \\
\hline
\end{tabular}

Table.2 Effect of nutrients and pest management on yield attributes, yield and economics of pigeonpea.

\begin{tabular}{|c|c|c|c|c|c|c|}
\hline Treatment & Pods/Plant & Grain/pod & $\begin{array}{c}\mathbf{1 0 0} \\
\text { seed } \\
\text { wt.(g) }\end{array}$ & Yield(kg/ha) & $\begin{array}{c}\text { Gross } \\
\text { Income } \\
\text { (Rs./ha) }\end{array}$ & B:Cratio \\
\hline $\begin{array}{c}\text { RDF } \\
\text { RDF +2\% urea spray at 50\% }\end{array}$ & 204.55 & 3.67 & 7.88 & $2,123.44$ & $095,555.00$ & 2.37 \\
\hline $\begin{array}{c}\text { flowering } \\
\text { RDF +0.5\% B spray at 50\% } \\
\text { flowering }\end{array}$ & 209.11 & 4.22 & 8.16 & $2,417.12$ & $108,770.40$ & 2.68 \\
\hline $\begin{array}{c}\text { RDF +0.5\% Zn spray at 50\% } \\
\text { flowering }\end{array}$ & 208.11 & 4.11 & 8.10 & $2,421.34$ & $108,960.40$ & 2.69 \\
\hline $\begin{array}{c}\text { RDF +2\% urea+0.5\% B+0.5\% Zn } \\
\text { spray at 50\% flowering }\end{array}$ & 208.88 & 4.11 & 8.57 & $2,559.01$ & $115,155.40$ & 2.83 \\
\hline $\begin{array}{c}\text { RDF +Multi-micronutrient spray } \\
\text { @ 2mI/Its of water }\end{array}$ & 214.78 & 3.56 & 8.71 & $2,612.34$ & $117,555.50$ & 2.87 \\
\hline $\begin{array}{c}\text { RDF +Indoxacarb at } \\
\text { flowering+one systemic insecticide } \\
\text { 15 days after first spray }\end{array}$ & 209.88 & 3.56 & 9.30 & $2,633.65$ & $118,514.40$ & 2.89 \\
\hline $\begin{array}{c}\text { RDF +Indoxacarb at } \\
\text { flowering+one systemic insecticide }\end{array}$ & 213.33 & 4.56 & 8.50 & $2,779.45$ & $125,075.50$ & 3.04 \\
\hline 15 days after first spray & & & & & & \\
\hline SE(m) & 4.594 & 0.230 & 0.257 & 25.915 & $1,167.338$ & 0.029 \\
\hline C.D. & N/A & N/A & 0.786 & 79.368 & $3,575.060$ & 0.09 \\
\hline
\end{tabular}


Table.3 Simple correlation coefficients between growth and yield parameters of pigeonpea

\begin{tabular}{|c|c|c|c|c|c|c|}
\hline Characters & 1 & 2 & 3 & 4 & 5 & 6 \\
\hline Plant height (cm) & 1 & & & & & \\
\hline Branch Plant $^{-1}$ & -0.589 & 1 & & & & \\
\hline Pods Plant $^{-1}$ & -0.420 & 0.753 & 1 & & & \\
\hline Grain pod $^{-1}$ & -0.800 & 0.432 & 0.164 & 1 & & \\
\hline 100 seed wt. (g) & 0.307 & 0.424 & 0.562 & -0.245 & 1 & \\
\hline Yield (kg/ha) & -0.361 & 0.843 & 0.859 & 0.338 & 0.723 & 1 \\
\hline
\end{tabular}

Fig.1 Effect of nutrients and pest management on yield

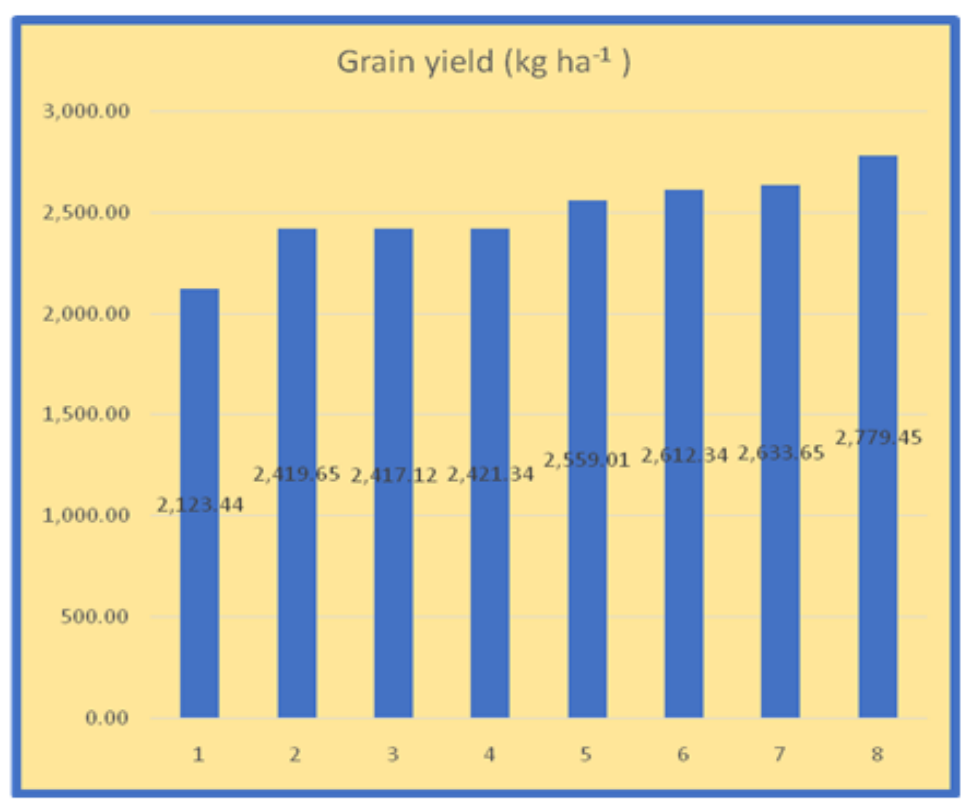

Fig.2 Effect of nutrients and pest management on Gross Income Rs/ha

\section{Gross Income Rs/ha}

$140,000.00$

$120,000.00$

$100,000.00$

$80,000.00$

$60,000.00$

$40,000.00$

$20,000.00$

0.00
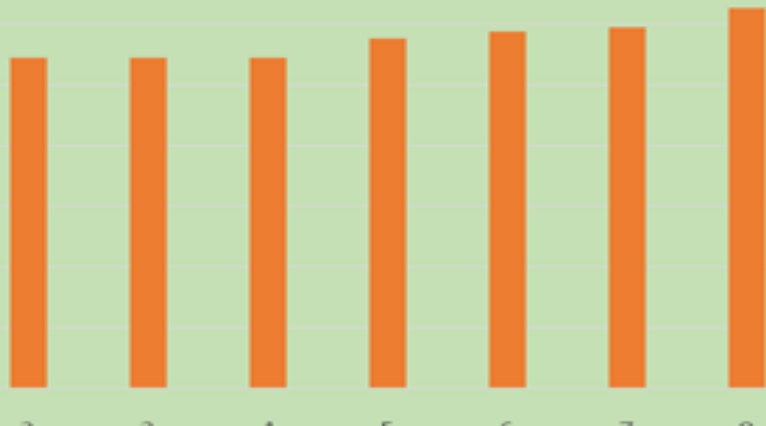

1 
Highest gross income was also obtained with treatment $\mathrm{T} 6$ + Indoxacarb at flowering + one systemic insecticide 15 days after first spray (125075.50 Rs. ha ${ }^{-1}$ ); closely followed by $\mathrm{RDF}+$ Indoxacarb at flowering + one systemic insecticide 15 days after first spray (118514.40 Rs. ha ${ }^{-1}$ ) and RDF + Multimicronutrient spray @ $2 \mathrm{ml} / \mathrm{lt}$ of water (117555.50 Rs. ha ${ }^{-1}$ ), which were $30.89 \%$, $24.02 \%$ and $23.02 \%$ higher than RDF (95555.00 Rs. ha ${ }^{-1}$ ). Similar findings was also reported by Jadhav and Kute (2019) and Kalaichelvi (2020).

This can be validated by the observed correlations among the above yield parameters with grain yield in the present study (Table 2). Similar findings and observations were also reported by Tekale et al., (2009); El-Seifi et al., (2013); Mukund et al., (2013) and Gowthami and Rama Rao (2014). B:C ratio was also recorded in the same manner, it was found highest with the application of T6 + Indoxacarb at flowering + one systemic insecticide 15 days after first spray (3.04); closely followed by RDF + Indoxacarb at flowering + one systemic insecticide 15 days after first spray (2.89), which were $28.27 \%$ and $21.94 \%$ more than RDF (2.37). These results are in accordance with the results reported by Kailas (2019). Growth, yield attributes and yield correlation also reflects the above findings (Table 3).

Results revealed that the application of T6 $(\mathrm{RDF}+2 \%$ urea $+0.5 \% \mathrm{~B}+0.5 \% \mathrm{Zn}$ spray at $50 \%$ flowering) + Indoxacarb at flowering + one systemic insecticide 15 days after first spray recorded highest grain yield $(2779.45 \mathrm{~kg}$ $\left.\mathrm{ha}^{-1}\right)$, gross income (125075.50 Rs. ha $\left.{ }^{-1}\right)$ and benefit cost ratio (3.04). Investigation reflect that by the use of T6 (RDF $+2 \%$ urea $+0.5 \%$ $\mathrm{B}+0.5 \% \mathrm{Zn}$ spray at $50 \%$ flowering) + Indoxacarb at flowering + one systemic insecticide 15 days after first spray was recorded 30.89\% higher grain yield and Gross income; and $28.27 \%$ higher $\mathrm{B}: \mathrm{C}$ cost ratio over the application of RDF. So, from overall comparison to RDF, particularly on economic point of view, we may have come in conclusion that the application of $\mathrm{RDF}+2 \%$ urea $+0.5 \% \mathrm{~B}+0.5 \% \mathrm{Zn}$ spray at $50 \%$ flowering + Indoxacarb $14.5 \% \mathrm{SC}$ at flowering + one systemic insecticide 15 days after first spray can be suggested for nutrient and pest management practice in long duration pigeonpea to attained the maximum grain yield and economic return.

\section{References}

A Report on Kharif Pulses Prospects, 2020-21 DPD, Bhopal pp. 2.

Ahlawat, I. P. S., Gangaiah, B. and Singh, I. P. 2005. Pigeonpea (Cajanus cajan) research in India-an overview. Indian Journal of Agricultural Sciences, 75 (6): 309-20

Anonymous, Annual report. (2017-18). Directorate of pulse development. http://dpd.gov.in/ Annual\%20Report\%20 2017-18.pdf.

Archana Verma, Uday Pratap Shahi, Pankaj Chaurasia and Laxman Kumawat. 2020. Effect of Mode of Micronutrients Application on Growth and Yield of Pigeon Pea (Cajanus cajan L.) in Sandy Loam Soil. Int.J.Curr.Microbiol.App.Sci. 9(03): 17-24. doi:

https://doi.org/10.20546/ijcmas.2020.903.00 3

Barik, T. and Rout, D. 1990. Effect of foliar spray of commercial micro-nutrient mixtures on growth, yield and quality of urdbean. Legume Research, 13(1): 50-52.

Elumle P., Shrirame, M. D. and Darade, G. A. 2019. Study of foliar nutrient management on growth and yield of pigeonpea (Cajanus cajan). Journal of Pharmacognosy and Phytochemistry, 8(4): 2497-2499.

El-Seifi, S. K., Hassan, M. A. and Al-Saeed, M. A. 2013. Effect of foliar spray with some micronutrients on growth, yield and chemical composition of pigeonpea. J. Plant Production, 4 (4): $685-691$.

Gowthami, P. and Rama Rao, G. 2014. Foliar application potassium, boron and zinc on 
growth and yield of soybean. Int. J. of Food, Agric. and Veterinary Sci., 4 (3): 81-86.

Gomez, A. A. and Gomez, A. A. 1984. Statistical Procedures for Agricultural Research (2ndedition). John Wiley and Sons. Singapore.

Gowda, K. M., Halepyati, A. S., Hoshamani, V., Koppalkar, B. G., Rao, S. and Prashanth, K.M. 2015. Nutrient uptake of Pigeon Pea (Cajanus cajan L. Millsp) as influenced by soil application of micronutrients and foliar spray of macronutrients, Environment and Ecology. 33(3): 1059- 1061.

Gopalan, C., Rama Sastri, B. V. and Balasubramanian, S. C. 1971. Nutritive value of Indian Foods. National Institute of Nutrition (NIN), Hyderabad, India.p-204

Kumar Rao, J. V. D. K. 1990. Pigeon pea: nitrogen fixation. Pp: 233-256 (in) The Pigeon pea (Eds.; Y L Nene, S D Hall and V K Sheila), $\mathrm{CAB}$ international, Wallingford, UK

Kumar Rao, J. V. D. K. and Dart, P.J. 1987. Nodulation, Nitrogen fixation and N2 uptake in pigeon pea (Cajanus cajan L. Millsp.) of different maturity groups. Plant \& Soil, 99: 255-266

Jadhav, V. T. and Kute, N. S. 2019. Nutrient and pest management practices for enhancing growth and yield of pigeonpea (Cajanas cajan L.). Journal of Food Legumes. 2019; Vol.32(3): 206-207.

Kailas, H. Veeresh, K. Narayana Rao, S. R. Balanagoudar and Sharanagouda, H. 2019. Effect of Conventional and Nano Micronutrient Fertilizers on Yield and Economics of Pigeonpea [Cajanus cajan (L.) Mill sp.]. Int.J.Curr.Microbiol.App.Sci.8(09): 185-193.

doi:https://doi.org/10.20546/ijcmas.2019.809 .024 .

Kaur G, Ghai N, Kaur J, Singh S. 2015. Growth Efficiency and Yield of Pigeonpea (Cajanus cajan L.) as Affected by Foliar Application of Mineral Nutrients. J Plant Sci Res. 2015;2(2): 130.

K Kalaichelvi. 2020. Yield influence with nutrient, weed and pest management in redgram (Cajanus cajan). Int $\mathrm{J}$ Chem Stud 2020;8(5):2265-2267.

DOI: 10.22271/chemi.2020.v8.i5ae.10642

Muthal, Y. C., Deshmukh S. L., Sagvekar V. V. and Shinde, J. B. 2016. Response of foliar application of macro and micronutrients on growth, yield on quality of kharif green gram (Vigna radiata L.) International Journal of Tropical Agriculture. 2016; 34(7): 21372141.

Mukund, G. K., Halepyati, A. S., Koppalkar, B. G. and Satyanarayana, 2013, Response of pigeonpea (Cajanus cajan L. Millsp.) to application of micronutrients through soil and foliar spray of macronutrients on yield, economics and protein content. Kar. J. Agric. Sci., 27 (4): 460-463.

Rajesh Kumar and Sharma, S. C. 2020. Effect of Insecticides and Foliar Nutrients Application on Growth, Yield and Economics of Pigeon Pea (Cajanus cajan L.) under Hadoti Region of Rajasthan. Int.J.Curr.Microbiol.App.Sci. 9(09): 3022-3027.

doi:https://doi.org/10.20546/ijcmas.2020.909 .373 .

Tekale, R. P., Arti, G. and Kavita, A., 2009, Impact of boron, zinc and IAA on growth, dry matter accumulation and sink potential of pigeonpea (Cajanus cajan L.). Agric. Sci. Digest. 29 (4): 246-249.

Thamke S. S. 2017. Studies on effect of graded levels of potassium and zinc on growth, yield, nutrient uptake and quality of pigeon pea. Thesis (Unpublished) Submitted to Vasantrao Naik Marathwada Krishi Vidhyapeeth, Prabhani.

\section{How to cite this article:}

Akhilesh Mishra and Geeta Rai. 2021. Response of Late Sown Pigeonpea (Cajanus cajan (L.) Mill Sp.) to Nutrient and Pest Management. Int.J.Curr.Microbiol.App.Sci. 10(11): 35-42. doi: https://doi.org/10.20546/ijcmas.2021.1011.005 